\title{
Development of passive immunotherapy for control of infectious hematopoietic necrosis
}

\author{
S. E. LaPatra, K. A. Lauda, G. R. Jones, S. C. Walker, W. D. Shewmaker \\ Clear Springs Foods, Inc., PO Box 712, Buhl, Idaho 83316, USA
}

\begin{abstract}
When rainbow trout Oncorhynchus mykiss (mean weight, $4.3 \mathrm{~g}$ ) were injected with $100 \mu \mathrm{l}$ of anti-infectious hematopoietic necrosis virus (IHNV) rainbow trout immune serum (IHNV neutralizing titer 640) immediately following waterborne exposure to $10^{5}$ plaque-forming units $\mathrm{ml}^{-1}$ of IHNV, relative protection was $91 \%$ compared to fish injected with normal serum (titer $<20$ ). Fish injected with immune serum at 24 and $48 \mathrm{~h}$ post-exposure to virus exhibited relative protection of 88 and $75 \%$, respectively. Less protection was observed in fish injected 3 or $4 \mathrm{~d}$ post-exposure. Endogenously produced virus neutralizing titers in surviving fish injected at 0 and $24 \mathrm{~h}$ post-exposure were not detected but fish injected at $48 \mathrm{~h}$ produced a significant humoral response. Juvenile rainbow trout (mean weight $1 \mathrm{~g}$ ) receiving injections of $50 \mathrm{\mu l}$ of serum having a low plaque neutralization titer of 20 to 40 resulted in relative protection of 67 to $82 \%$ compared to fish injected with saline. When the same volume of a higher-titered serum was injected, greater protection was generally observed. These results suggested that low neutralization titers could be sufficient for significant protection against IHN disease. In 1 field trial, mortality due to IHN was lower in the group that received the passive immunotherapy compared to a group that was left untreated.
\end{abstract}

KEY WORDS: Rhabdovirus - Rainbow trout - Passive immunization

\section{INTRODUCTION}

Strategies currently used to prevent and minimize economic impact due to disease in the intensive culture of rainbow trout Oncorhynchus mykiss include prudent fish health management (e.g. pathogen-free water supplies, bird exclusion devices), vaccination (induction of active immunity), and treatment with therapeutants. Passive immunity examined experimentally by injection of sera from immune trout to naive trout has been found to provide protection from fish pathogens including Vibrio anguillarum (Harrell et al. 1975), Yersinia ruckeri (Oleson 1991), and infectious hematopoietic necrosis virus (IHNV; Amend \& Smith 1974). Passive serum transfer has been examined as a prophylactic and/or therapeutic strategy in the field for the control of furunculosis in 3 salmonid species (Turgeon \& Elazhary 1992). Although injection was required and duration of protection was limited, this strategy could be useful on valuable or small fish populations. Additionally, passive immunization studies can provide important information about immunogenic proteins, requirement for multiple vaccine strains, pathogenesis of microorganisms, and titer of antibody required for protection. We previously reported on protection against IHNV after passive transfer of anti-IHNV immune serum (LaPatra et al. 1993). When rainbow trout (mean weight, $1 \mathrm{~g}$ ) were injected with 50 to $200 \mu \mathrm{l}$ of pooled serum from juveniles (IHNV neutralizing titer 1280) or adults (titer 640) that had experienced a natural infection with IHNV and had survived, relative protection was 63 to $100 \%$ against IHNV compared to rainbow trout injected with normal serum (titer $<20$ ) or saline. The objectives of this study were to determine (1) if injection of fish serum having IHNV neutralizing activity effectively reduced mortality at different times post-exposure to IHNV, (2) if fish that were protected by passively transferred antibodies still responded humorally, (3) the minimum neutralization titer of serum required for protection after passive transfer, and (4) if passive immunotherapy could be used as an IHN management strategy. 


\section{MATERIALS AND METHODS}

Passive immunotherapy and virus challenges. Virus challenges and passive immunizations were done using procedures previously described for laboratory testing of passive immunity (LaPatra et al. 1991, 1993). Briefly, standardized waterborne exposures to IHNV $\left[10^{5}\right.$ plaque-forming units (pfu) $\left.\mathrm{ml}^{-1}\right]$ were done in an amount of water equaling 10 times the total weight $(\mathrm{g})$ of the fish for $1 \mathrm{~h}$ in closed systems with aeration. For passive immunization, fish were anesthetized and injected intraperitoneally (ip) with rainbow trout immune serum (IHNV neutralization titer $\geq 20$ ), normal serum (titer, <20), or saline. A group of 1500 Clear Springs stock rainbow trout (mean weight $4.3 \mathrm{~g}$ ) was waterborne-exposed to $10^{5} \mathrm{pfu} \mathrm{ml}^{-1}$ of IHNV isolate $220-90$, and 300 additional fish from the same population were handled similarly but not exposed to the virus. Immediately post-exposure (time 0 ) and at $24 \mathrm{~h}$ intervals for $4 \mathrm{~d}, 100$ fish were removed from the IHNV-infected group and 50 of these were injected ip with $100 \mu \mathrm{l}$ of rainbow trout immune serum (IHNV neutralizing titer 640) or normal serum. Each 50 fish treatment group at each test interval was split into duplicate 25 fish subgroups in separate $19 \mathrm{l}$ aquaria supplied with $15^{\circ} \mathrm{C}$ spring water treated by ultraviolet light. Additionally, 25 sham-infected fish were injected with immune or normal serum immediately postexposure and at $48 \mathrm{~h}$ intervals for $4 \mathrm{~d}$ and placed in separate aquaria. Mean cumulative percent mortality and relative percent protection were calculated for each group. Cumulative percent mortality of the replicates was analyzed by analysis of variance (ANOVA)

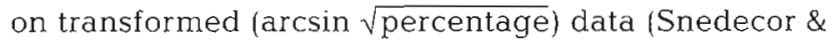
Cochran 1967) and pairwise comparisons were done with the Mann-Whitney Rank Sum Tests using the Sigma Stat statistical software (Jandel Scientific Co.).

Control and challenged fish from each of the treatment groups were bled $28 \mathrm{~d}$ after exposure to virus for determination of serum neutralization titers using a complement dependent $50 \%$ plaque neutralization titer (PNT) assay (LaPatra et al. 1993, Ristow et al. 1993). Briefly, blood was obtained from fish that had been lethally anesthetized, either by caudal puncture or by caudal severance. Blood samples were placed at $4{ }^{\circ} \mathrm{C}$, allowed to clot, and centrifuged for $10 \mathrm{~min}$ at $1600 \times \mathrm{g}$. Serum samples were heat-inactivated at $45^{\circ} \mathrm{C}$ for 30 min and a 2 -fold dilution series was made. An equal volume of diluted IHNV (2000 $\mathrm{pfu} \mathrm{ml}^{-1}$ ) and complement (1 10 dilution), obtained from diseasefree rainbow trout that had not been fed for at least $2 \mathrm{wk}$, was added to each serum dilution. Samples were plaque assayed in duplicate for each serum dilution tested on epithelioma papulosum cyprini (EPC) monolayers. Anti-IHNV neutralization titers were reported as the reciprocal of the highest serum dilution that resulted in a $50 \%$ reduction in the average number of plaques detected in negative controls. Significant differences among treatments were analyzed by a chi-square test.

Minimum neutralization titer for protection. Two studies were done to determine the minimum neutralization titer of trout serum required for protection in juvenile rainbow trout (mean weight $1 \mathrm{~g}$ ) after passive transfer. In the first study, 50 rainbow trout were injected with $50 \mu \mathrm{l}$ of trout serum having a $50 \%$ PNT of $1280,320,80$, or 20 . In the second study 50 fish were injected with $50 \mu \mathrm{l}$ of trout serum that had a $50 \%$ PNT of $640,160,40$, or 10 . In each test, the lower antibody concentrations were made by diluting serum having a starting titer of 1280 or 640 with phosphate buffered saline (PBS) in 4 -fold increments. One group of fish in each test was injected with PBS only. Duplicate 25 fish groups from each treatment were challenged with $10^{5}$ pfu $\mathrm{ml}^{-1}$ of IHNV by standard procedures. Control fish were injected with $50 \mu$ l of undiluted immune serum and handled similarly but not exposed to virus. Average cumulative percent mortality and mean number of days to death were calculated for each group. Cumulative percent mortality of the replicates was analyzed by ANOVA on transformed data and pairwise comparisons were done using the MannWhitney Rank Sum Tests. Relative percent protection (RPP) for groups injected with immune serum was calculated by the following formula:

RPP =

$1-\frac{\text { (cumulative } \% \text { mortality in fish injected with immune serum) }}{\text { (cumulative } \% \text { mortality in fish injected with normal serum) }}$

Passively immunized groups for all tests were held in separate $19 \mathrm{l}$ aquaria, and monitored for mortalities for $28 \mathrm{~d}$. Each day, at least $20 \%$ of the fish that died on that day were examined for virus. Virus concentrations of whole fish or kidney-spleen-liver homogenates were determined. Quantitation of virus used in fish exposures or isolated from dead fish was accomplished by plaque assay procedures (LaPatra et al. 1989).

Passive immunization field tests. A group of approximately 2000 fish (mean weight $64 \mathrm{~g}$ ) were diagnosed with spontaneous infectious hematopoietic necrosis (IHN) after a slight increase in mortality. Half of this group (1000 fish) were each injected ip with $1 \mathrm{ml}$ of serum containing IHNV-neutralizing antibodies (titer 640) to determine the effectiveness of passive immunotherapy in the field. Fish were monitored for mortality and 15 from each treatment group were nonlethally bled every $2 \mathrm{wk}$ for $10 \mathrm{wk}$ beginning $14 \mathrm{~d}$ post-injection to determine IHNV neutralization titers. 


\section{RESULTS}

\section{Passive immunization after exposure to IHNV}

Fish injected with immune serum immediately after exposure to IHNV exhibited relative protection of $91 \%$ compared to fish injected with normal serum. Fish injected at 24 and $48 \mathrm{~h}$ post-exposure exhibited relative protection of 88 and $75 \%$, respectively, compared to controls. Less protection was observed in fish injected at the later time intervals (Table 1). There was not a significant difference ( $p>0.5$ ) among all mean cumulative percent mortality values for fish challenged with IHNV and either injected with immune or normal serum. However, there was a significant difference $(p=0.02)$ in the mean values between the different treatments over all days post-infection. Virus was detected in $87 \%(111 / 127)$ of the dead rainbow trout examined. Virus concentrations determined on 50 of these fish ranged from $10^{2}$ to $>10^{7.3} \mathrm{pfu}^{-1}$ with a mean titer of $10^{6} \mathrm{pfu}^{-1}$

\section{IHNV neutralization activity in fish serum}

Fish injected with immune serum at 0 and 24 h postexposure to IHNV exhibited low mortality, and antibody concentrations in surviving fish were significantly different ( $\mathrm{p}<0.03$ ) than in IHN-survivors injected with normal serum. However, fish injected $48 \mathrm{~h}$ postexposure produced a strong humoral response and were also effectively protected (Table 2). Antibody titers detected in these fish were not significantly different $(p>0.05)$ from those of IHN-survivors injected with normal serum. Control fish not challenged with IHNV but injected with immune serum still had a low level of neutralizing activity $(\geq 20)$ in the serum after the experimental period whereas control fish injected with normal serum had no detectable anti-IHNV activity. Additionally, survivors that were injected with immune serum just post-exposure to IHNV (time 0) had more antibody-negative fish than control fish injected with immune serum but not exposed to IHNV.

\section{Passive immunotherapy field trial}

The results of 1 field trial indicated that approximately $44 \%$ fewer fish were lost in the immune serum injected group (43/1000) compared to the group that was not injected (77/1000). Non-lethal blood samples obtained at 2 wk intervals showed that passively immunized rainbow trout had higher prevalences of antiIHNV positive fish and higher mean antibody titers at 2 and 4 wk post-injection. The control group generally had higher mean titers and prevalences toward the end of the sampling period $(6,8$, and $10 \mathrm{wk}$ ) (Table 3 ).

\section{Passive immunization threshold level of protection}

Two experiments indicated that injection of $50 \mu \mathrm{l}$ of serum with a PNT of 20 to 40 into $1 \mathrm{~g}$ rainbow trout provided relative protection of 67 to $82 \%$. If the same volume of higher-titered serum was delivered, greater protection was generally observed (Table 4). There was a highly significant difference $(p=0.003)$ in the first test in the mean cumulative percent mortality values for fish injected with immune serum compared to fish injected with saline. There was not a significant difference $(p>0.5)$ in the mean values for fish injected with immune serum. In the second test there was also a highly significant difference $(p=0.0001)$ in cumulative percent mortality for fish injected with immune serum compared to fish injected with saline. However, there was also a significant difference $(p<0.05)$ in mortality for fish injected with immune serum diluted 1:64 (estimated titer 10) compared to other immune serum injected groups. Virus was detected in $84 \%$

Table 1. Oncorhynchus mykiss. Cumulative mortalities in young rainbow trout challenged with infectious hematopoietic necrosis virus (IHNV) after passive transfer of immune serum beginning immediately after exposure to IHNV (time 0 ) and at $24 \mathrm{~h}$ intervals for $4 \mathrm{~d}$. Trout either waterborne-exposed to $10^{5} \mathrm{pfu} \mathrm{m}^{-1}$ IHNV or sham-exposed, were injected with normal serum (titer $<20$ ) or immune serum (titer 640 ) that contained anti-IHNV antibodies. Relative protection: \% of fish injected with immune serum compared to fish injected with normal serum and challenged with IHNV; nd = not done

\begin{tabular}{|c|c|c|c|c|c|}
\hline \multirow{3}{*}{$\begin{array}{l}\text { Time post- } \\
\text { infection } \\
\text { (d) }\end{array}$} & \multicolumn{4}{|c|}{ Cumulative mortality $(\%)$} & \multirow{3}{*}{$\begin{array}{l}\text { Relative protection } \\
\qquad(\%)\end{array}$} \\
\hline & \multicolumn{2}{|c|}{ IHNV-exposed } & \multicolumn{2}{|c|}{ Sham-exposed } & \\
\hline & Immune & Normal & Immune & Normal & \\
\hline 0 & $6(3 / 49)$ & $69(35 / 51)$ & $4(1 / 24)$ & $4(1 / 24)$ & 91 \\
\hline 1 & $8(4 / 50)$ & $69(34 / 49)$ & nd & nd & 88 \\
\hline 2 & $18(9 / 50)$ & $72(36 / 50)$ & $0(0 / 24)$ & $0(0 / 25)$ & 75 \\
\hline 3 & $42(21 / 50)$ & $60(30 / 50)$ & nd & nd & 30 \\
\hline 4 & $50(25 / 50)$ & $70(35 / 50)$ & $0(0 / 25)$ & $8(2 / 25)$ & 29 \\
\hline
\end{tabular}


Table 2. Oncorhynchus mykiss. IHNV antibody titers detected $28 \mathrm{~d}$ post-exposure in IHNV-exposed and sham-treated groups. Fish (mean weight $4.3 \mathrm{~g}$ ) were injected with $100 \mu \mathrm{l}$ of immune serum (IHNV neutralizing titer 640) or with normal serum. Results given as the highest serum titer resulting in a $50 \%$ reduction in the number of plaques detecled in negative serum controls ns: no sample

\begin{tabular}{|c|c|c|c|c|c|c|c|c|}
\hline \multirow[t]{2}{*}{ Fish no. } & \multirow[b]{2}{*}{ Day injected: } & \multicolumn{4}{|c|}{ IHNV-exposed } & \multicolumn{3}{|c|}{ Sham-exposed } \\
\hline & & 1 & 2 & 3 & 4 & 0 & 2 & 4 \\
\hline \multicolumn{9}{|c|}{ Fish injected with immune serum } \\
\hline 1 & 40 & 20 & 160 & 320 & 80 & $<20$ & 20 & $<20$ \\
\hline 2 & 20 & 20 & 320 & 80 & 80 & 20 & 20 & 80 \\
\hline 3 & $<20$ & 80 & 40 & 160 & 160 & 20 & 20 & 80 \\
\hline 4 & 20 & 20 & $\geq 640$ & 160 & 160 & 80 & 80 & ns \\
\hline 5 & $<20$ & $<20$ & 320 & 320 & 320 & 40 & $<20$ & ns \\
\hline 6 & $<20$ & 80 & 160 & ns & ns & ns & ns & ns \\
\hline 7 & 20 & 20 & 40 & ns & ns & ns & ns & ns \\
\hline 8 & $<20$ & 20 & 160 & ns & ns & ns & ns & ns \\
\hline \multicolumn{9}{|c|}{ Fish injected with normal serum } \\
\hline 1 & 160 & 80 & 80 & 160 & $\geq 640$ & $<20$ & $<20$ & $<20$ \\
\hline 2 & 80 & 160 & 160 & 160 & 320 & $<20$ & $<20$ & $<20$ \\
\hline 3 & 160 & $\geq 640$ & $\geq 640$ & 160 & 160 & $<20$ & $<20$ & $<20$ \\
\hline 4 & ns & ns & ns & $\geq 640$ & $\mathrm{~ns}$ & $\mathrm{~ns}$ & $\mathrm{~ns}$ & ns \\
\hline
\end{tabular}

$(43 / 51)$ and $92 \%(61 / 66)$ of the dead rainbow trout examined in each experiment. Virus concentrations determined on 75 of these fish ranged from $10^{2}$ to $>10^{7.3} \mathrm{pfu}^{-1}$ with a mean titer of $10^{6.4} \mathrm{pfu}^{-1}$.

\section{DISCUSSION}

The passive transfer of anti-IHNV serum by injection into fish 0 to $48 \mathrm{~h}$ after exposure to high concentrations of IHNV provided relative protection of 75 to $91 \%$ compared to fish injected with normal serum. Less protection was observed in fish injected at the later time points. Water temperature has been shown to effect mean number of days (MDD) to death in rainbow trout waterborne exposed to IHNV and may influence the efficacy of passive immunization. Hetrick et al. (1979) reported the MDD was only 7 d at $18^{\circ} \mathrm{C}$ compared to $17 \mathrm{~d}$ at $3^{\circ} \mathrm{C}$. These tests were conducted at water temperatures of $15^{\circ} \mathrm{C}$ which is considered the optimum for replication of IHNV (Wolf 1988). The mean days-to-death in IHNV exposed groups injected with normal serum averaged $7.6 \mathrm{~d}$ (data not shown) but good protection was only observed up to $48 \mathrm{~h}$ postexposure to IHNV. Perhaps the virus had induced irreversible tissue damage after 48 h such that there could be no recovery of fish regardless of passive serum transfer. Tests of passive serum transfer with salmonids reared at colder temperatures may be more effective over longer durations because viral pathogenesis would be slowed. The half-life of the exogenously supplied immunoglobulin may also be extended because of decreased metabolic activity of fish in cooler water. The salmonid species tested as well as size and age may also affect results because these have been shown to impact IHNV-susceptibility (LaPatra et al. 1990). Additionally, dose of viral challenge and susceptibility differences within an experimental group are important parameters to consider when interpreting results for development of passive immunotherapy strategies.

Passively transferred immune serum provided immediate protection against IHN disease, but for longer

Table 3. Oncorhynchus mykiss. Neutralizing antibody titers to IHNV detected in rainbow trout surviving a natural infection of IHNV as part of a field evaluation for the passive immunization strategy. PNT: plaque neutralization titer

\begin{tabular}{|c|c|c|c|c|c|c|}
\hline \multirow{2}{*}{$\begin{array}{l}\text { Time post- } \\
\text { injection ( } \mathrm{wk} \text { ) }\end{array}$} & \multicolumn{3}{|c|}{ Immune serum injected } & \multicolumn{3}{|c|}{ Non-injected } \\
\hline & Proportion PNT-positive & PNT mean & PNT range & Proportion DNT-positive & PNT mean & PNT range \\
\hline 2 & $8 / 15$ & 19 & $<20-80$ & $3 / 15$ & 5 & $<20-40$ \\
\hline 4 & $10 / 15$ & 44 & $<20-320$ & $8 / 15$ & 23 & $<20-80$ \\
\hline 6 & $11 / 15$ & 43 & $<20-160$ & $13 / 15$ & 91 & $<20-320$ \\
\hline 8 & $3 / 15$ & 43 & $<20-320$ & $7 / 15$ & 16 & $<20-80$ \\
\hline 10 & $1 / 15$ & 3 & $<20-40$ & $10 / 15$ & 31 & $<20-160$ \\
\hline
\end{tabular}


Table 4. Oncorhynchus mykiss. Passive immunization of rainbow trout (mean weight $1 \mathrm{~g}$ ) with different concentrations of trout anti-lHNV immune serum. A titer of 0 indicates injection with $50 \mu$ phosphatebuffered saline; control fish were injected with $50 \mu$ l of serum with a neutralization titer of 640 and handled equivalently but not exposed to virus. nm: no mortality

\begin{tabular}{|cccc|}
\hline $\begin{array}{c}\text { Anti-IHNV } \\
\text { neutralization } \\
\text { titer }\end{array}$ & $\begin{array}{c}\text { Average } \\
\text { cumulative } \\
\text { mortality }(\%)\end{array}$ & $\begin{array}{c}\text { Mean } \\
\text { days-to-death }\end{array}$ & $\begin{array}{c}\text { Relative } \\
\text { protection }(\%)\end{array}$ \\
\hline Test 1 & & & \\
1280 & $4(2 / 46)$ & 9 & 96 \\
320 & $2(1 / 49)$ & 23 & 98 \\
80 & $15(7 / 46)$ & 19 & 84 \\
20 & $32(16 / 50)$ & 17 & 67 \\
0 & $96(47 / 49)$ & 9 & \\
Control & $0(0 / 20)$ & $n m$ & \\
& & & \\
Test 2 & & 15 & 79 \\
640 & $21(10 / 48)$ & 16 & 82 \\
160 & $26(12 / 47)$ & 16 & \\
40 & $18(9 / 50)$ & 14 & \\
10 & $57(26 / 46)$ & 8 & \\
0 & $100(50 / 50)$ & $n$ & \\
Control & $0(0 / 20)$ & & \\
& & & \\
\hline
\end{tabular}

serum injected group compared to the group that was not injected. However, in both cases the mortality was low. The fish were large (64 g) when mortality due to IHN was detected and were divided into 2 separate raceways. Reducing fish densities possibly helped moderate the severity of the epizootic in both groups. Handling stresses associated with injection may also have exacerbated the disease. However, the passively immunized group that was injected and moved to a different raceway still had less mortality than the unhandled controls. Similar trends of antibody titers and prevalence of antibody-positive fish detected in the passively immunized group were also observed in experimental groups injected at different times after waterborne exposure to IHNV. Passively transferred antibodies were used in defense of an IHNV infection and reduced a specific immune response because antigen concentration was kept low. The results from the untreated fish are also in agreement with previous studies that examined the antibody kinetics in unimmunized fish

duration of protection a specific humoral response would be required. Fish injected with IHNV-immune serum at 0 and $24 \mathrm{~h}$ post-exposure to IHNV exhibited low mortality and negligible antibody concentrations in surviving fish, whereas, fish injected $48 \mathrm{~h}$ postexposure produced a significant humoral response and were also effectively protected. Additionally, survivors of IHN that were injected with immune serum immediately after exposure to IHNV (time 0) had more antibody-negative fish than control fish injected with immune serum but not exposed to IHNV. A possible explanation is that challenged fish were depleted of exogenous antibody through binding with specific antigen during the defense against an IHNV-infection. Passively transferred antibody minimizes disease by neutralizing virus infecting the host but it may also inhibit a specific immune response by reducing antigen concentration below the threshold required for humoral stimulation. Ellis et al. (1992) reported that exposure of vaccinated fish to high and persistent Aeromonas salmonicida levels accelerated the decrease in protective antibody levels. Some antibody may also be degraded and lost due to normal metabolic processes. Hence, after the 28 d monitoring period, minimal passively transferred antibody was detected in immune serum injected mock-infected controls.

Passive immunotherapy could be used as an emergency management strategy if an important group of fish were diagnosed with IHN in the early stages of an epizootic. The results of 1 field trial indicated that approximately $44 \%$ fewer fish were lost in the immune exposed to IHNV. Low titers and prevalences were detected at $2 \mathrm{wk}$ but all fish responded with high titers by 6 wk (LaPatra et al. 1993).

The minimum IHNV neutralizing titer required to achieve protection against clinical disease has been unclear. This information is important for the development of effective passive immunization therapies. Our 2 experiments indicated that injection of $50 \mu \mathrm{l}$ of serum with a PNT of 20 to 40 into $1 \mathrm{~g}$ rainbow trout provided relative protection of 67 to $82 \%$. If the same volume of a higher-titered serum was delivered, greater protection was generally observed. These results suggest that low IHNV neutralizing activity, whether obtained by passive immunization or by other strategies, could provide protection or minimize the severity of an IHN epizootic. Antibody titers reported for IHN survivors are highly variable (Hattenberger-Baudouy et al. 1989, Jørgensen et al. 1991, Ristow et al. 1993). However, in naturally infected populations, protection against reinfection is generally observed (Busch 1983) suggesting that low antibody titers are sufficient for strong protection. Although decreased susceptibility to IHNV has been reported with increasing fish size and age (LaPatra et al. 1990) IHN epizootics have been reported in large (100 to $500 \mathrm{~g}$ ) rainbow trout (Busch 1983) and Atlantic salmon Salmo salar (Armstrong et al. 1993). Because mortality in large fish can have severe economic consequences, passive immunotherapy may be a potential strategy for use on valuable fish. Our results suggest that this type of strategy may have the immediate benefit of reduced mortality and 
may also allow for endogenous humoral immunity. Monitoring of IHNV neutralizing antibody concentrations could also be used as a predictor of the IHNV susceptibility of a group of fish and the effectiveness of IHN control strategies. Future studies should investigate the practicality of producing large volumes of anti-IHNV antiserum that would be required for widespread use of passive immunotherapy and the use of purified immunoglobulin rather than serum for prevention of sensitization and/or serum sickness if reinjections are required.

Acknowledgements. We thank John R. MacMillan, Clear Springs Foods, Inc., and Chris Bayne, Oregon State University, Corvallis, for their review of the manuscript. We also thank Doug Foss and Jerry Giles for their excellent technical assistance and Scott Williams for statistical analyses (all from Clear Springs Foods).

\section{LITERATURE CITED}

Amend, D. F., Smith, L. (1974). Pathophysiology of infectious hematopoietic necrosis virus disease in rainbow trout (Salmo gairdneri): early changes in blood and aspects of the immune response after injection of IHN virus. J. Fish. Res. Bd Can. 31: 1371-1378

Armstrong, R., Robinson, J., Rymes, C., Needham, T. (1993). Infectious hematopoietic necrosis in Atlantic salmon in British Columbia. Can. Vet. J. 34: 312-313

Busch, R. A. (1983). Viral disease considerations in the commercial trout industry in Idaho. In: Leong, J. C., Barila, T. Y. (eds.) Workshop on viral diseases of salmonid fishes in the Columbia River basin. Special Publication, Bonneville Power Administration, Portland, OR, p. 84-100

Ellis, A. E., Bricknell, I. R., Munro, A. L. S. (1992). Current status of a Scottish furunculosis vaccine. Bull. Aquacult. Ass. Can. 92(1): 11-15

Harrell, L. W., Etlinger, H. M., Hodgins, H. O. (1975). Humoral factors important for resistance of salmonid fish to bacterial disease. I. Serum antibody protection of rainbow trout (Salmo gairdnen) against vibriosis. Aquaculture 6: $211-219$

Hattenberger-Baudouy, A. M., Danton, M., Merle, G., Torchy,

Responsible Subject Editor: F. M. Hetrick, College Park, Maryland, USA
C., de Kinkelin, P. (1989). Serological evidence of infectious hematopoietic necrosis in rainbow trout from a French outbreak of disease. J. aquat. Anim. Health 1. $126-134$

Hetrick, F. M., Fryer, J. L., Knittel, M. D. (1979). Effect of water temperature on the infection of rainbow trout Salmo gairdneri Richardson with infectious hematopoietic necrosis virus. J. Fish Dis. 2: 253-25?

Jørgensen, P. E. V., Olesen, N. J., Lorenzen, N., Winton, J. R., Ristow, S. S. (1991). Infectious hematopoietic necrosis (IHN) and viral hemorrhagic septicemia (VHS): detection of trout antibodies to the causative viruses by means of plaque neutralization, immunofluorescence, and enzymelinked immunosorbent assay. J. aquat Anim. Health 3 : $100-108$

LaPatra, S. E., Groberg, W. J., Rohovec, J. S., Fryer, J. L. (1990). Size-related susceptibility of salmonids to two strains of infectious hematopoietic necrosis virus. Trans. Am. Fish. Soc. 119: 25-30

LaPatra, S. E., Lauda, K. A., Morton, A. W. (1991). Antigenic and virulence comparison of eight isolates of infectious hematopoietic necrosis virus from the Hagerman Valley, Idaho, USA. In: Proceedings of the Second International Symposium on Viruses of Lower Vertebrates. Oregon State University Press, Corvallis, p. 125-129

LaPatra, S. E., Roberti, K. A., Rohovec, J. S., Fryer, J. L. (1989) Fluorescent antibody test for the rapid diagnosis of infectious hematopoietic necrosis. $J$ aquat. Anim. Health 1 . $29-36$

LaPatra, S. E., Turner, T., Lauda, K. A., Jones, G. R., Walker, S (1993). Characterization of the humoral response of rainbow trout to infectious hematopoietic necrosis virus J. aquat. Anim. Health 5: 165-171

Olesen, N. J. (1991). Detection of the antibody response in rainbow trout following immersion vaccination with Yersinia ruckeri bacterins by ELISA and passive immunization. $J$ appl. Ichthyol. $7: 36-43$

Ristow, S, S., de Avila, J., LaPatra, S. E., Lauda, K. A. (1993). Detection and characterization of rainbow trout antibody against infectious hematopoietic necrosis virus. Dis. aquat. Org. 15: 109-114

Snedecor, G. W., Cochran, W. G. (1967). Statistical methods, 6 th edn. Iowa State University Press, Ames

Turgeon, Y., Elazhary, Y. (1992). Furunculosis control with antiAeromonas salmonicida hyperimmune serum (SHAAS). Bull. Aquacult. Ass. Can. 92(1): 64-67

Wolf, K. (1988). Fish viruses and fish viral diseases. Comstock Publishing Associates, Ithaca, NY, p. 83-114

Manuscript first received: February 1, 1994

Revised version accepted: May 16, 1994 